\title{
Statistical Analysis of Physiological Parameters with Seed Yield of Indian Mustard
}

\author{
Omprakash Godara*, B.L. Kakraliya, Sajjan Choudhary, Ajit Singh and \\ Raj Kumar Fagodiya
}

Department of plant physiology, Department of Agricultural Economics and Department of Plant

Pathology, SKN Agriculture University Jobner-303329, Rajasthan, India

*Corresponding author

A B S T R A C T

\section{Keywords \\ Test weight, Seed yield, Harvest index and Biological yield. \\ Article Info \\ Accepted: \\ 14 July 2017 \\ Available Online: \\ 10 September 2017}

\section{Introduction}

High temperature stress negatively affects plant growth, development and crop yield (Boyer, 1982). According to recent study (Lobel and Asner, 2003) each degree centigrade increases in average growing season temperature reduce and crop yield $17 \%$. High temperature stress directly or indirectly affect plant photosynthetic rate by changing the structural organization and physio-chemical properties of thylakoid membrane (Lichtenthaler et al., 2005).

The rate of photorespiration increases with increase temperature which reduces net photosynthesis (Sage and Sharkey, 1987) and probably the seed yield of the crop.

\section{Materials and Methods}

\section{Statistical analysis}

The experimental data recorded for growth, yield and other characters were statistically analysed by Panse and Sukhatme (1985). Appropriate standard error for each of the factor was worked out. Significance of differences among treatment effects was tested by " $F$ " test.

Critical difference (CD) was worked out wherever the difference was found to be significant at 5 or 1 per cent level of significance. The analysis of variance of different components for all parameters is given in the appendices at the end. 


\section{Results and Discussion}

\section{Correlation analysis}

The correlation analysis indicated that most of the parameters have positive correlation with seed yield of Indian mustard (Tables 1 and 2).
Relative water content, photosynthetic rate, chlorophyll stability index and membrane stability index showed significant and positive correlation with seed yield. Whereas, seed yield was negatively correlated with transpiration rate, stomatal conductance and leaf temperature.

Table.1 Simple correlation coefficient of physiological parameters with seed yield of Indian mustard

\begin{tabular}{|c|c|c|}
\hline \multirow[t]{2}{*}{ Parameters } & \multicolumn{2}{|c|}{ Correlation coefficient (r) } \\
\hline & Flowering & Siliqua initiation \\
\hline Yield v/s & & \\
\hline (i) Relative water content & $0.911 * *$ & $0.920 * *$ \\
\hline (ii) Photosynthetic rate & $0.933^{* *}$ & $0.907 * *$ \\
\hline (iii) Transpiration rate & $-0.956 * *$ & $-0.911 *$ \\
\hline (iv) Stomatal conductance & -0.113 & -0.050 \\
\hline (v) Leaf temperature & $-0.873 * *$ & $-0.889 * *$ \\
\hline (vi) Chlorophyll stability index & $0.902^{* *}$ & $0.909 * *$ \\
\hline (vii) Membrane stability index & $0.942 * *$ & $0.934 * *$ \\
\hline
\end{tabular}

Table.2 Simple correlation coefficient of chlorophyll stability and membrane stability index, yield and yield attributes with seed yield of Indian mustard

\begin{tabular}{lc}
\hline Parameters & Correlation coefficient (r) \\
\hline Yield v/s & \\
(i) Oil content & $0.842^{* *}$ \\
(ii) Days to 50 per cent flowering & $0.642^{* *}$ \\
(iii) Plant height & $0.951^{* *}$ \\
(iv) Number of siliquae per plant & $0.970^{* *}$ \\
(v) Number of seeds per siliqua & $0.965^{* *}$ \\
(vi) Test weight & $0.834^{* *}$ \\
(vii) Biological yield & $0.900^{* *}$ \\
(viii) Harvest index & $0.920^{* *}$ \\
*indicates significance at 5 per cent levels; **indicates significance at 1 per cent levels
\end{tabular}

However, stomatal conductance showed negative correlation but the response was non-significant (Table 2).

Oil content, yield attributes, biological yield and harvest index were showed positive and significant correlations with seed yield. Correlation of number of siliquae per plant, number of seeds per siliqua, test weight, biological yield and harvest index were highly significant with seed yield (Table 2).

\section{References}

Boyer, A., 1982. Effect of high temperature stress negatively affects plant growth development and crop yield of mustard. Indian Journal of Agronomy 13(2): 243- 
190.

Buttar, G.S., and Aulakh, C.S. 1999. Effect of sowing date, nitrogen and row spacing on growth, yield attributes and yield of Indian mustard (Brassica juncea). Indian J. Agron., 44(4): 813-815.

Chandra, A., Dubey, A. 2007. Effect of salicylic acid on morphological and bio chemical attributes in cowpea. Journal of Environmental Biology. 28(2) 193196

Chandra, D., 1997. Effect of agronomic practices on the performance of rapeseed (Brassica campestris) and Indian mustard (Brassica juncea) varieties in post rice season of coastal Orissa. J. Oilseeds Res., 14(2): 194-201.
Chandrakar, B.L., and Urkurkar, J. S., 1993. Performance of mustard varieties to dates of sowing in rice fallow. Ind. J. Agron., 38(1): 143-144.

Chauhan, Y.S., and Singh, D. 2008. Inheritance of seed weight in Indian mustard (Brasica juncea L.). Indian J. Genet. And Pl. Breed. 40:597.

Lichtenthaler, S.K., 2005. Photosynthetic response of corn and soybean to foliar application of salicylates. Indian Journal of Agricultural Sciences, 74(1):53-98.

Lobel, G.H., Asner P.K. 2003. Effect of high temperature on crop growth and yield. Progress. Agriculture, 49:23-99.

\section{How to cite this article:}

Omprakash Godara, B.L. Kakraliya, Sajjan Choudhary, Ajit Singh and Raj Kumar Fagodiya. 2017. Statistical Analysis of Physiological Parameters with Seed Yield of Indian Mustard. Int.J.Curr.Microbiol.App.Sci. 6(9): 720-722. doi: https://doi.org/10.20546/ijcmas.2017.609.088 